\title{
Kesan Suplementasi Tokotrienol ke atas Perubahan Hormon dan Katekolamin Otak Tikus Aruhan Stres
}

(Effect of Tocotrienol Supplementation on Hormones and Catecholamines in the Brain of Rats Exposed to Stress)

\author{
NuR AZLINA MOHD FAHAMI*, NADDIAH SyAFIQAH RAMLI \& ELDA SURHAIDA LATIF
}

\begin{abstract}
ABSTRAK
Stres merupakan sebarang gangguan, cabaran atau ancaman kepada seseorang individu yang merangsang perubahan respon fizikal, mental dan emosi. Hormon stres dan katekolamin dirembeskan di dalam otak sebagai respon terhadap stres. Kajian ini mengenal pasti kesan tokotrienol tulen dan vitamin E sawit ke atas perubahan hormon stres dan katekolamin pada tikus yang diaruhkan stres imobilisasi rendaman air. Sebanyak 32 ekor tikus Wistar jantan telah dibahagikan secara rawak kepada empat kumpulan kajian. Dua kumpulan kawalan; kumpulan tanpa stres (NS) dan kumpulan tanpa stres (CS) serta dua kumpulan rawatan yang diberikan tokotrienol (TTS) atau vitamin E sawit (TFS) secara oral paksaan pada dos $60 \mathrm{mg} / \mathrm{kg}$ berat badan selama 28 hari. Setelah tamat tempoh rawatan, tikus daripada kumpulan CS, TTS dan TFS telah didedahkan kepada stres imobilisasi rendaman air selama tiga setengan jam. Kemudian, otak tikus diambil untuk pengukuran hormon pelepasan kotikotrofin (CRH), hormon adenokortikotropik (ACTH), norepinefrin, dopamin dan serotonin. Keputusan kajian mendapati peningkatan kandungan CRH, ACTH, norepinefrin dan dopamine di dalam otak tikus yang diaruh stres berbanding kumpulan kawalan tanpa stres. Kandungan serotonin pula menurun akibat stres. Walau bagaimanapun, tikus yang diberi suplementasi tokotrienol dan vitamin E sawit menunjukkan penurunan signifikan kandungan $\mathrm{CRH}, \mathrm{ACTH}$, norepinefrin dan dopamin serta peningkatan kandungan dan serotonin sehingga hampir ke aras normal. Tiada perbezaan antara pemberian tokotrienol dan vitamin $E$ sawit. Sebagai kesimpulan, tokotrienol dan vitamin E sawit berkesan dalam mengawal perubahan hormon stres serta katekolamin pada otak tikus yang teraruh stres.
\end{abstract}

Kata kunci: Hormon stres; katekolamin; otak; stres restrain; tokotrienol

\section{ABSTRACT}

Stress includes any disturbances, challenges or threats to an individual, which stimulates physical, mental and emotional responses. Stress hormones and catecholamines are released from the brain in response to stress. Antioxidant properties of vitamin $E$ had been proven to help in reducing stress. This study was designed to investigate the effects of tocotrienol and palm vitamin E supplementation on stress hormones and catecholamines in stress-induced rats. Thirty two male Wistar rats were randomly assigned into four groups, consisted of two control groups (NS and CS) which were fed with a commercially prepared normal rat diet while two treatment groups (TTS and TFS) were given tocotrienol or palm vitamin E orally in the dose of $60 \mathrm{mg} / \mathrm{kg}$ body weight. After 28 days of treatment; CS, TTS and TFS rats were subjected to water-immersion restraint stress for three and a half hours once. The rats were killed and their brain was taken to determine stress hormones and catecholamines levels. The findings showed that stressed (CS) rats had a significantly higher levels of $C R H, A C T H$, norepinephrine and dopamine and lower level of serotonin in the brain. Interestingly, supplementation with both tocotrienol and palm vitamin E were able to significantly reduced the CRH, ACTH, norepinephrine and dopamine levels. No difference was observed when comparing the effects of tocotrienol with palm vitamin E. In conclusion, tocotrienol and palm vitamin E are capable in reducing changes to the stress hormones and catecholamines in stress-induced rats.

Keywords: Brain; catecholamines; palm vitamin E; restraint stress; stress hormones; tocotrienol

\section{PENDAHULUAN}

Tekanan atau stres diketahui boleh membawa impak negatif terhadap minda dan badan. Pendedahan kepada stres yang berulangan atau berpanjangan boleh menyebabkan perubahan kepada hormon stres yang seterusnya meningkatkan risiko terhadap pelbagai masalah kesihatan (Lundberg 2002). Disebabkan kesan buruk stres, pelbagai cara, kaedah atau terapi telah dijalankan bagi mengurangkan stres untuk mengelakkan impak negatifnya kepada kesihatan manusia.

Menurut American Psychological Association, bancian stres di Amerika pada tahun 2017, menunjukkan angka stres yang semakin meningkat dari tahun ke tahun dan hampir 75\% rakyat Amerika mengalami stres. Punca stres yang paling utama di Amerika adalah tekanan kewangan seterusnya diikuti dengan faktor pekerjaan dan 
kesihatan. Lebih membimbangkan lagi apabila responden daripada bancian tersebut juga turut menyatakan bahawa tahap stres mereka begitu serius sehingga boleh membawa kepada masalah kesihatan yang kronik seperti penyakit jantung, diabetes dan kemurungan.

Manakala di Malaysia, menurut kajian oleh penyedia pekerjaan global pada tahun 2013, Regus Research, menganggarkan hampir $70 \%$ peratus pekerja di negara ini mengalami stres akibat keadaan ekonomi global yang tidak menentu, serta mereka menyatakan bahawa stres boleh menyumbang kepada risiko obesiti, kencing manis, masalah gastorusus dan asma. Perkara ini menunjukkan bahawa stres juga merupakan salah satu penyumbang dan penyebab kepada berlakunya penyakit-penyakit kronik kepada manusia.

Stres boleh disebabkan daripada punca dalaman mahupun luaran dari persekitaran. Ia merangsang perubahan fisiologi badan untuk mengaktifkan sistem endokrin bagi mengawal reaksi stres melalui penghasilan glukokortikoid seperti kortisol dan hormon katekolamin seperti epinefrin dan norepinefrin (Romero \& Butler 2007; Tsigos et al. 2016). Kortisol, juga dikenali sebagai 'hormon stres', terlibat dalam sistem regulasi terhadap reaksi stres dan berfungsi dalam mengawal kadar gula di dalam darah untuk memastikan sistem tubuh mempunyai tenaga yang mencukupi, seterusnya mengembalikan sistem tubuh kepada homeostasis normal. Selain itu, stres juga menyebabkan penghasilan neurotransmitter iaitu katekolamin seperti dopamin, norepinefrin dan epinefrin dengan neurotransmitter ini kemudian akan merangsang aktiviti amigdala di dalam otak yang bertanggungjawab dalam meregulasi respon emosi (Tsigos et al. 2016). Norepinefrin dan epinefrin juga berfungsi dalam mengaktifkan sistem saraf simpatetik untuk menghasilkan respon 'fight or flight', meningkatkan kadar denyutan jantung, meningkatkan kadar gula di dalam darah, menambah kepekaan mental serta merendahkan sistem pertahanan badan (Tort \& Teles 2011).

Walau bagaimanapun, penghasilan hormon stres iaitu kortisol yang tidak terkawal boleh membawa kesan buruk apabila peningkatan hormon kortisol ketika stres boleh menyebabkan pengurangan hormon serotonin di dalam otak lantas menyumbang kepada kemurungan (Mahar et al. 2014). Serotonin, atau juga dikenali sebagai 'hormon gembira' ialah sejenis neurotransmiter yang terlibat di dalam kawalan selera, tidur, memori dan belajar, regulasi suhu, tingkah laku ragam, tingkah laku seksual, fungsi sistem kardiovaskular, kontraksi otot dan regulasi sistem endokrin (Cowen et al. 2002; Mahar et al. 2014).

Di dalam reaksi stres, dopamin turut dihasikan disebabkan pengikatan hormon kortisol di reseptor glukokortikoid pada saraf neuron dopamin, lantas melepaskan dopamin dari terminal saraf (Gamo et al. 2015). Dopamin yang meningkat di prefrontal korteks telah menyumbang kepada pengurangan memori bekerja lalu boleh mengakibatkan masalah mental dan pengurangan fungsi kognitif. Tambahan lagi, aktiviti hormon kortisol ketika stres juga telah mempengaruhi dan meningkatkan penghasilan hormon dopamin di adrenal medulla (Marinelli \& Piazza 2002). Selain itu, neurotransmitter asetilkolin, epinefrin dan norepinefrin juga turut meningkat di dalam keadaan stres.

Kesan buruk akibat pendedahan yang terlalu lama kepada hormon stres dapat dikurangkan dengan pengambilan vitamin E kerana vitamin E telah dibuktikan dapat mengurangkan hormon stres seperti glukokortikoid dan katekolamin (Nur Azlina \& Nafeeza 2008; Nur Azlina et al. 2012). Vitamin E adalah sejenis vitamin penting larut lemak dan mengandungi dua jenis kompoun iaitu tokoferol dan tokotrienol. Antara sumber tokotrienol ialah kelapa sawit, minyak annatto dan juga dapat dikesan di dalam susu ibu (Aggarwal 2010). Dalam kajian yang lepas, tokotrienol telah menunjukkan kesan antioksidan yang lebih baik berbanding toloferil (Bandharn et al. 2011), tokotrienol juga mampu mengurangkan kadar penghasilan hormon stres iaitu kortikosteron dengan cara mengurangkan sumber penghasilan kortikosteron iaitu kolesterol (Hood 1995). Tokotrienol sawit juga dilaporkan mampu menghalang kecederaan otak (Budin et al. 2014), melambatkan penuaan otak daripada segi memori (Taridi et al.2014) dan mampu mengekalkan tahap kortikosteron dan tahap norepinefrin pada julat hormon tahap tidak stres (Ibrahim et al. 2012).

Justeru, kajian ini dijalankan untuk melihat keberkesanan tokotrienol dalam mengurangkan penghasilan hormon dan katekolamin yang terlibat dalam respon stres, lantas dapat mencegah kesan buruk daripada keadaan stres. Dalam kajian ini, aktiviti dan keberkesanan tokotrienol dapat dikenal pasti daripada pengukuran hormon dan katekolamin daripada otak tikus.

\section{METODOLOGI}

Sebanyak tiga puluh dua ekor tikus Sprague-Dawley dengan berat antara 180-220 g telah dibahagikan secara rawak kepada empat kumpulan iaitu kumpulan kawalan, kumpulan tanpa rawatan dan dua kumpulan rawatan. Semua kumpulan diberi makanan diet yang normal. Sebagai tambahan, kumpulan kawalan (NS) dan kumpulan stres tanpa rawatan (CS) diberi minyak zaitun manakala kumpulan rawatan mendapat makanan tambahan iaitu Vitamin E sawit (TFS) atau tokotrienol (TTS). Vitamin E sawit dan tokotrienol diberi secara oral pada dos $60 \mathrm{mg} /$ $\mathrm{kg}$ berat badan selama 28 hari. Selepas tempoh rawatan selama 28 hari, kumpulan tikus rawatan dan kumpulan CS telah didedahkan kepada keadaan stres melalui kaedah imobilisasi stres dan rendaman air atau turut juga dikenali sebagai 'water immersion restraint stres' (WIRS) dan dijalankan selama 3.5 jam sekali. Selepas tempoh pendedahan kepada stres, tikus kajian dikorbankan secara dos lewah anastesia dan organ otak diambil dan disimpan di dalam cecair nitrogen di $-80^{\circ} \mathrm{C}$. Dos rawatan yang telah diberi adalah berdasarkan kajian oleh Ibrahim et al. (2012) dan Nur Azlina et al. (2008) yang menunjukkan kesan penurunan kortikosteron pada tikus yang diaruh stres. 
Kesemua tikus dipelihara pada kitaran siang/malam yang normal serta pada tempoh cahaya asli selama lebih kurang dua belas jam (0700 sehingga 1900 jam). Sepanjang tempoh pemeliharaan, persekitaran habitat tikus perlulah di dalam keadaan yang tidak mendatangkan gangguan atau tekanan dengan tikus dipelihara di dalam sangkar yang cukup besar mengikut kapasiti dan saiz tikus itu sendiri. Makanan dan air diberi ad libitum sepanjang tempoh uji kaji dijalankan. Tikus dipuasakan semalaman, sehari sebelum tikus didedahkan kepada WIRS. WIRS adalah satu kaedah yang dijalankan dengan cara meletakkan tikus di dalam plastik restrainer secara indvidu dan kemudiannya akan direndam di dalam air sehingga ke tahap leher tikus pada suhu bilik $\left(23^{\circ} \mathrm{C}\right)$ selama 3.5 jam (Nur Azlina et al. 2015). Penyelidikan ini telah diluluskan oleh Etika Haiwan UKM (UKMAEC: FSK/BIOMED/ELDA/13-NOV/557).

Sebelum proses homogenisasi, bahagian otak yang spesifik terhadap setiap hormon dan katekolamin diasingkan. Bahagian hipotalamus digunakan untuk mengukur aras hormon pelepasan kortikotrofin (CRH) dan hormon adrenokortikotropik (ACTH), bahagian serebelum untuk mengukur norepinefrin, bahagian batang otak untuk mengukur dopamin, bahagian lobus frontal untuk mengukur serotonin dan bahagian serebral untuk mengukur asetilkolin. Proses homogenasi tisu otak dilakukan sebelum pemeriksaan hormon CRH (Cloud Clone Corp), ACTH (Cloud Clone Corp), norepinefrin (Cloud Clone Corp), dopamin (Cloud Clone Corp) dan serotonin (IBL International) menggunakan kit ELISA dijalankan.

Analisis statistik dilakukan dengan menggunakan perisian SPSS versi 23 selepas data diperoleh daripada uji kaji. Ujian normaliti dilakukan terlebih dahulu untuk menentukan ketaknormalan taburan data. Melalui uji kaji ini, taburan data adalah normal. Ujian ANOVA digunakan bagi menentukan kewujudan perbezaan pada parameter yang diukur antara kumpulan kajian. Post-hoc Tukey telah digunakan bagi menentukan perbezaan antara dua kumpulan. Nilai $p<0.05$ menunjukkan bahawa terdapat perbezaan yang signifikan. Semua nilai keputusan uji kaji adalah dinyatakan dalam bentuk purata \pm SEM.

\section{HASIL}

Rajah 1 menunjukkan purata kepekatan hormon CRH di hipotalamus dalam kumpulan normal, stres, vitamin E sawit+stres dan tokotrienol+stres. Kumpulan CS tanpa rawatan menunjukkan peningkatan hormon CRH yang ketara dan signifikan $(p<0.05)$ berbanding kumpulan NS iaitu sebanyak $1.16 \pm 0.57 \mathrm{pg} / \mathrm{mL}$. Purata kepekatan hormon CRH di dalam kumpulan normal ialah 0.48 \pm 0.28 pg/mL. Manakala kedua-dua kumpulan rawatan TFS dan TTS berjaya menurunkan hormon CRH secara signifikan $(p<0.05)$ berbanding kumpulan stres tanpa rawatan di dalam otak tikus yang didedahkan kepada imobilisasi stres di dalam rendaman air. Walau bagaimanapun, tiada perbezaan signifikan yang dapat dilihat $(p>0.05)$ antara kumpulan rawatan TFS $(0.40 \pm 0.22 \mathrm{pg} / \mathrm{mL})$ dan TTS $(0.34 \pm 0.07 \mathrm{pg} / \mathrm{mL})$ dalam keupayaan merendahkan penghasilan hormon CRH.

Rajah 2 menunjukkan analisis ELISA terhadap kepekatan hormon ACTH. Di dalam kumpulan stres tanpa rawatan $(80.01 \pm 51.12 \mathrm{pg} / \mathrm{mL})$, peningkatan hormon ACTH secara signifikan $(p<0.05)$ dapat dikesan berbanding kumpulan tikus normal $(28.79 \pm 5.19 \mathrm{pg} / \mathrm{mL})$. Kumpulan rawatan TFS $(31.19 \pm 10.99 \mathrm{pg} / \mathrm{mL})$ dan TTS $(31.66 \pm 7.19$ $\mathrm{pg} / \mathrm{mL}$ ) berjaya menunjukkan penurunan hormon yang signifikan $(p<0.05)$ berbanding kumpulan stres tanpa rawatan. Keberkesanan kumpulan rawatan TFS dan TTS dalam menurunkan sekresi hormon ACTH menunjukkan tiada perbezaan yuang signifikan $(p=0.93)$.

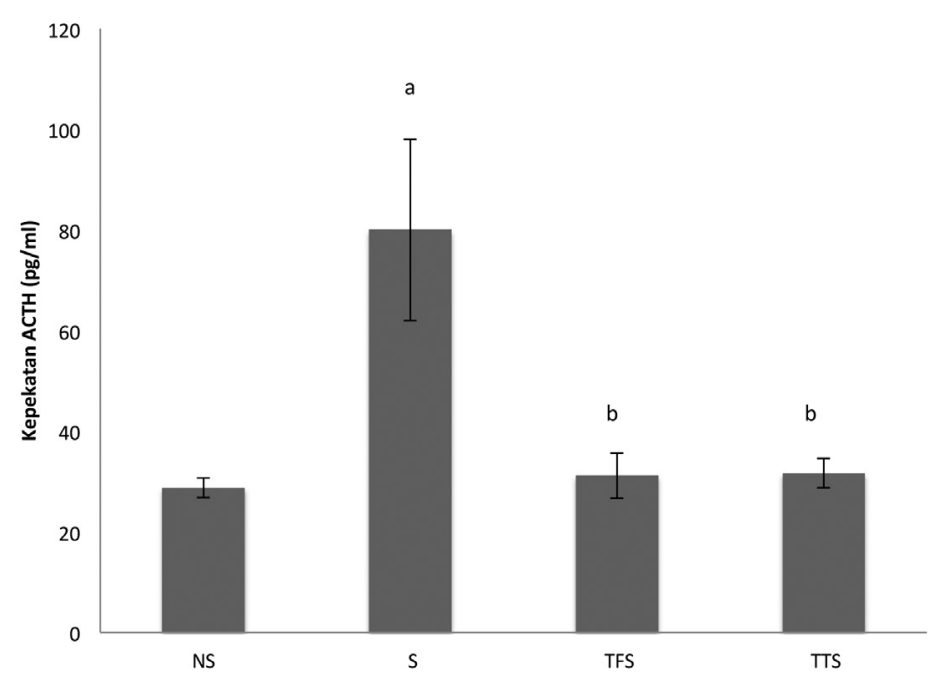

Nilai dinyatakan dalam bentuk purata \pm sisihan piawai

${ }^{a}$ Signifikan untuk perbandingan dengan kumpulan normal

b Signifikan untuk perbandingan dengan kumpulan stres tanpa rawatan

RAJAH 1. Perbandingan kepekatan CRH antara kumpulan normal (NS), stres (CS), Vitamin E sawit+stres (TFS) dan tokotrienol+stres (TTS) 


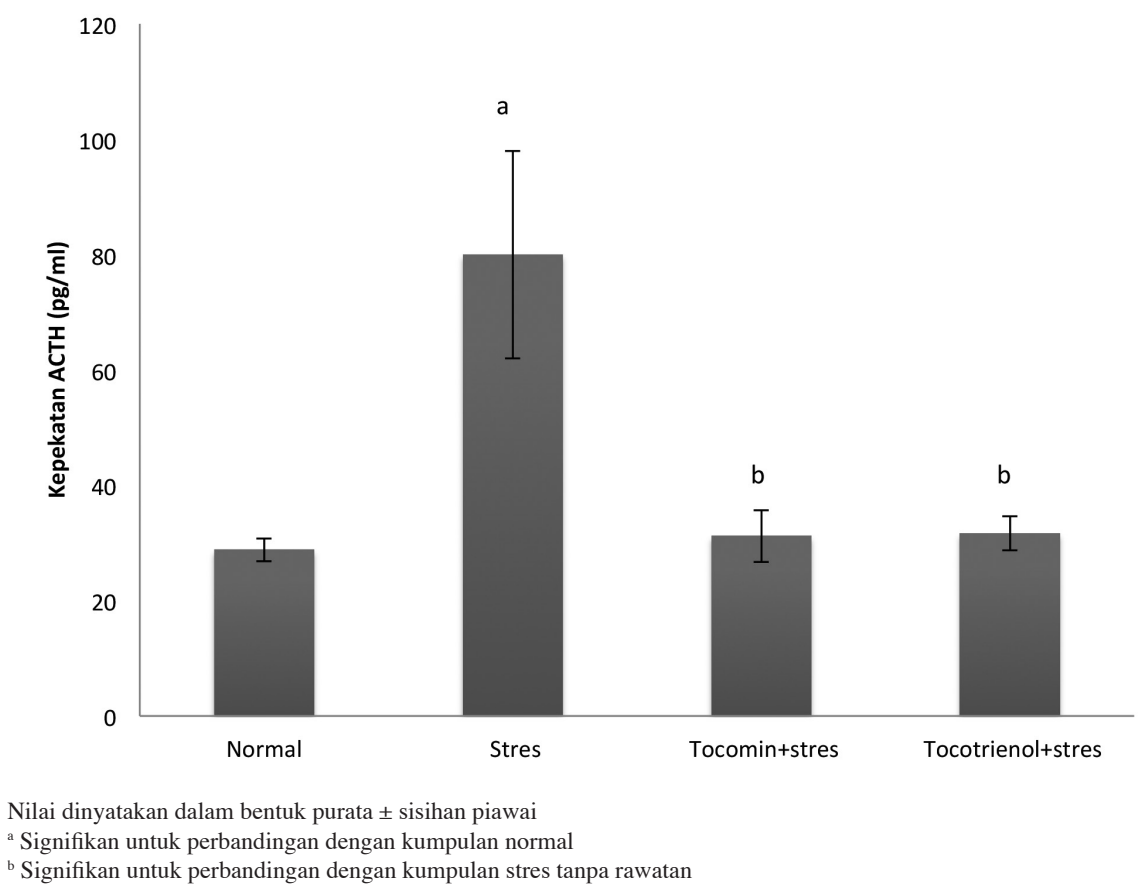

RAJAH 2. Perbandingan kepekatan hormon ACTH antara kumpulan normal (C), stres (CS), Vitamin E sawit+stres (TFS) dan tokotrienol+stres (TTS)

Analisis ELISA dalam Rajah 3 menunjukkan perbandingan aras kepekatan norepinefrin di serebelum otak tikus. Kumpulan tikus CS $(7.44 \pm 3.59 \mathrm{pg} / \mathrm{mL})$ menunjukkan peningkatan dalam penghasilan norepinefrin berbanding kumpulan NS $(1.58 \pm 0.60 \mathrm{pg} / \mathrm{mL})$ secara signifikan $(p<0.05)$. Penghasilan hormon norepinefrin berjaya dikurangkan dalam kumpulan tikus rawatan TFS $(2.74 \pm 2.08 \mathrm{pg} / \mathrm{mL})$ dan TTS $(3.97 \pm 1.16 \mathrm{pg} / \mathrm{mL})$ secara signifikan $(p<0.05)$ berbanding kumpulan tikus stres.
Walau bagaimanapun, tiada perbezaan signifikan dalam penurunan hormon norepinefrin antara kedua-dua tikus rawatan TFS dan TTS $(p=0.23)$.

Rajah 4 menunjukkan hasil analisis ELISA hormon dopamin di batang otak. Aras penghasilan hormon dopamin pada kumpulan tikus stres $(24.34 \pm 12.26 \mathrm{pg} / \mathrm{mL})$ menunjukkan peningkatan penghasilan secara signifikan $(p<0.05)$ berbanding kumpulan normal $(5.81 \pm 3.14 \mathrm{pg} /$ $\mathrm{mL})$. Kumpulan rawatan TFS $(4.59 \pm 2.47 \mathrm{pg} / \mathrm{mL})$ dan TTS

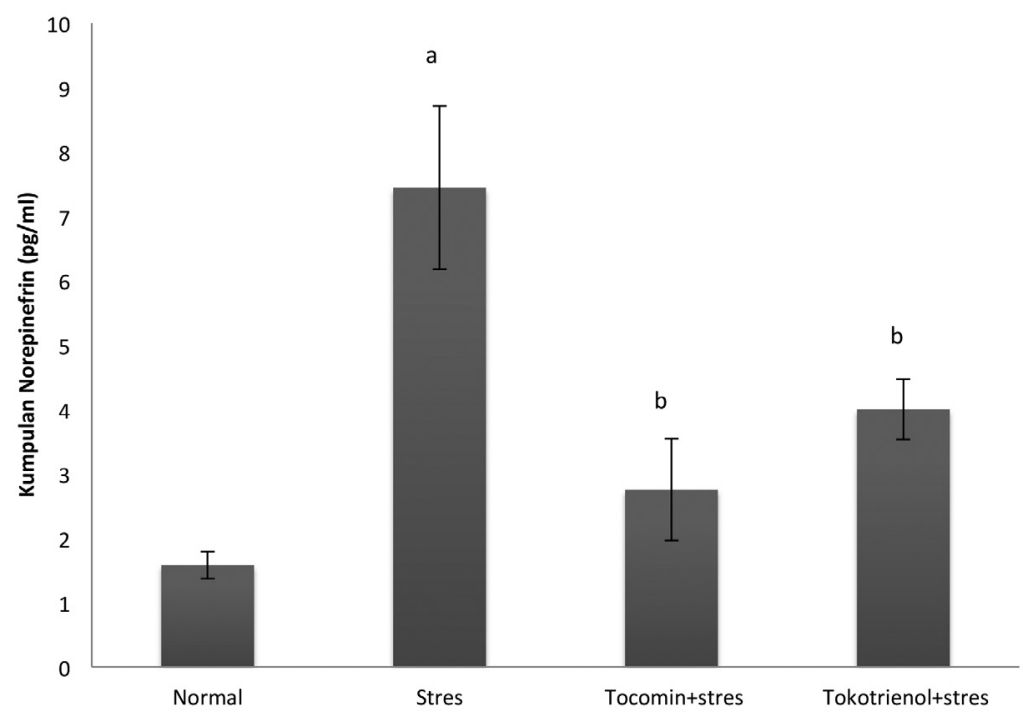

Nilai dinyatakan dalam bentuk purata \pm sisihan piawai

a Signifikan untuk perbandingan dengan kumpulan normal

${ }^{\mathrm{b}}$ Signifikan untuk perbandingan dengan kumpulan stres tanpa rawatan

RAJAH 3. Perbandingan kepekatan hormon norepinefrin antara kumpulan normal (C), stres (CS), Vitamin E sawit+stres (TFS) dan tokotrienol+stres (TTS) 


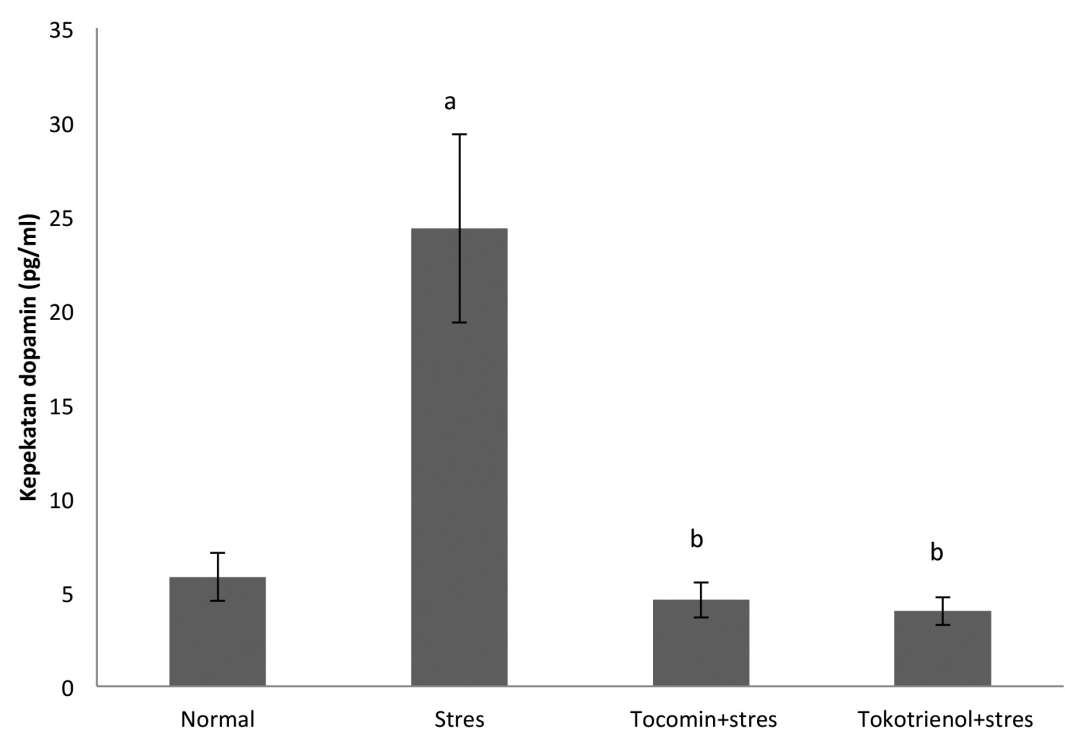

Nilai dinyatakan dalam bentuk purata \pm sisihan piawai

${ }^{a}$ Signifikan untuk perbandingan dengan kumpulan normal

${ }^{\mathrm{b}}$ Signifikan untuk perbandingan dengan kumpulan stres tanpa rawatan

RAJAH 4. Perbandingan kepekatan hormon dopamin antara kumpulan normal (C), stres (CS), Vitamin E sawit+stres (TFS) dan tokotrienol+stres (TTS)

$(3.99 \pm 2.08 \mathrm{pg} / \mathrm{mL})$ berjaya menunjukkan penurunan aras hormon dopamin secara signifikan berbanding kumpulan tikus stres. Penurunan aras hormon dalam kumpulan rawatan TFS dan TTS tidak mempunyai perbezaan yang signifikan $(p=0.62)$.

Rajah 5 menunjukkan aras kepekatan serotonin di lobus frontal otak tikus. Kumpulan tikus stres (12.94 \pm 0.91 $\mathrm{ng} / \mathrm{mL}$ ) menunjukkan penghasilan hormon serotonin yang lebih rendah berbanding kumpulan tikus normal $(15.72 \pm 0.47 \mathrm{mg} / \mathrm{mL})$ secara signifikan $(p<0.05)$. Aras hormon serotonin di dalam kedua-dua kumpulan tikus rawatan TFS $(14.41 \pm 0.55 \mathrm{ng} / \mathrm{mL})$ dan TTS $(14.59 \pm 0.58$ $\mathrm{ng} / \mathrm{mL}$ ) pula menunjukkan peningkatan hormon serotonin yang signifikan $(p<0.05)$ berbanding kumpulan tikus stres. Walau bagaimanapun, kedua-dua kumpulan rawatan TFS dan TTS tidak menunjukkan perbezaan yang signifikan $(p=0.57)$ di dalam aras peningkatan hormon serotonin.

\section{PERBINCANGAN}

Kehidupan moden dan era globalisasi masa kini telah menyebabkan stres menjadi situasi biasa yang terjadi dalam kehidupan seharian. Respon badan terhadap stres menyebabkan pelbagai tindak balas fisiologi berlaku seperti

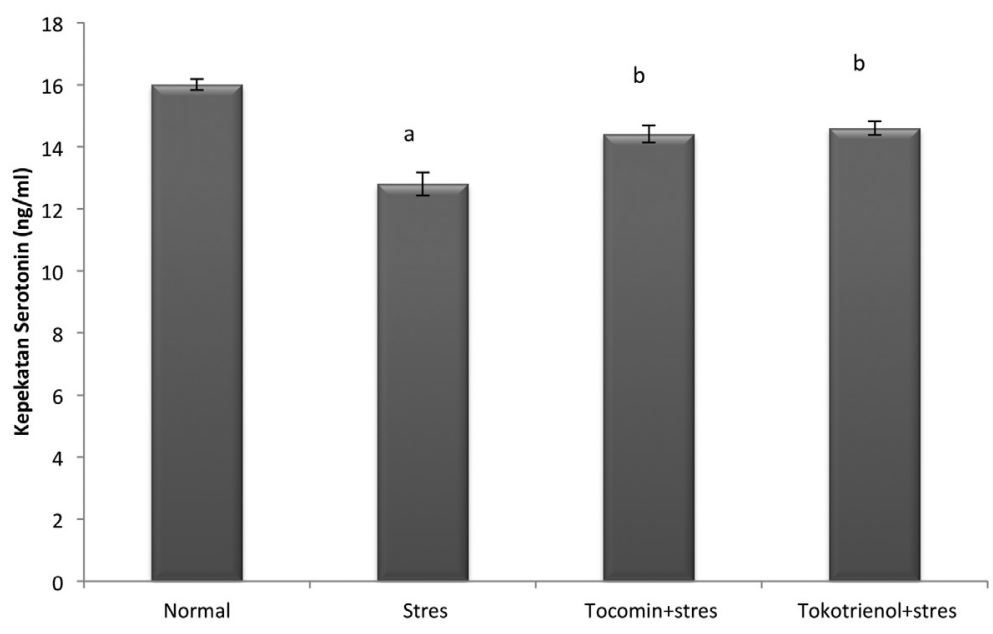

Nilai dinyatakan dalam bentuk purata \pm sisihan piawai

${ }^{a}$ Signifikan untuk perbandingan dengan kumpulan normal

${ }^{\mathrm{b}}$ Signifikan untuk perbandingan dengan kumpulan stres tanpa rawatan

RAJAH 5. Perbandingan kepekatan hormon serotonin antara kumpulan normal (C), stres (CS), Vitamin E sawit+stres (TFS) dan tokotrienol+stres (TTS) 
penghasilan pelbagai jenis hormon dan katekolamin dalam memastikan homeostasis tubuh badan dapat dikekalkan. Walau bagaimanapun, sekresi pelbagai molekul kimia ini boleh memberikan kesan buruk kepada sistem tubuh manusia dalam jangka masa panjang.

Keputusan kajian ini menunjukkan aras kepekatan hormon CRH meningkat di hipotalamus dalam kumpulan tikus yang didedahkan kepada imobilisasi stres dan rendaman air. Keputusan ini adalah selari dengan kajian (Hsu et al. 2001) yang turut menunjukkan peningkatan ekspresi mRNA CRH ketika stres akut berbanding stres yang berulang. Penghasilan hormon ACTH adalah selari dengan penghasilan hormon CRH dimana hormon ini juga meningkat dalam keadaan stres. Ini adalah kerana sekresi hormon CRH daripada hipotalamus akan menyebabkan penghasilan hormon ACTH daripada kalenjar pituitari. Peningkatan hormon ACTH ketika WIRS turut ditunjukkan oleh kajian Ibrahim et al. (2012). Seterusnya, hormon ACTH pula akan merangsang penghasilan hormon stres iaitu kortisol daripada bahagian korteks kalenjar adrenal. Penghasilan hormon kortisol melalui paksi hipotalamuspituitari-kalenjar adrenal adalah penting dalam meregulasi tindak balas terhadap stress. Walau bagaimanapun, pendedahan kepada stres secara berlebihan akan memberi impak negatif kepada kesihatan tubuh.

Keputusan kajian ini juga menunjukkan bahawa pemberian vitamin E sawit dan tokotrienol mampu mengurangkan penghasilan hormon $\mathrm{CRH}$ dan ACTH di hipotalamus sehingga hampir kepada aras normal berbanding kumpulan tikus stres tanpa rawatan, lantas pengurangan hormon ini juga akan menyebabkan pengurangan sekresi hormon kortisol. Sekresi hormon yang berkurangan ini mungkin disebabkan oleh aktiviti antioksidan vitamin E. Dalam situasi stres, berlaku peningkatan proses metabolisma badan yang akhirnya menyumbang kepada peningkatan radikal bebas di dalam badan.

Radikal bebas adalah molekul spesies reaktif yang kekurangan satu elektron dan tidak stabil, ia menyerang makromolekul seperti lipid, protin, karbohidrat dan DNA di dalam sel (Badharn et al. 2011). Radikal bebas yang berlebihan adalah berbahaya kerana boleh menyebabkan kerosakan tisu di dalam badan (Halliwell 2006). Otak merupakan salah satu organ sistem saraf yang menjadi sasaran radikal bebas kerana tisu otak mempunyai asid lemak tidak tepu dan aktiviti metabolik yang tinggi (Halliwell 1996).

Radikal bebas yang terhasil disebabkan peningkatan metabolisma badan semasa stres boleh menyerang reseptor glukokortikoid pada bahagian hipokampus (Schiavone et al. 2013). Reseptor glukokortikoid merupakan tapak ikatan bagi hormon kortisol dan hormon glukokortikoid yang lain. Kerosakan pada reseptor glukokortikoid akan menyebabkan tiada pengikatan berlaku antara hormon kortisol dan reseptor ini (Schiavone et al. 2013). Penghasilan hormon kortisol yang meningkat semasa stres akan mengaktifkan mekanisme suap-balik negatif untuk merencat sekresi hormon CRH dan ACTH pada hipotalamus dan kalenjar pituitari sebaik sahaja sesuatu stresor berakhir. Tetapi, radikal bebas yang berlebihan semasa stres boleh menyerang reseptor glukokortikoid di hipokampus dan merosakkan reseptor ini. Kerosakan pada reseptor ini akan menghalang mekanisme maklum balas negatif berlaku dan akhirnya hormon kortisol akan terus meningkat di dalam tubuh. Dalam kajian ini, rawatan vitamin E sawit dan tokotrienol yang digunakan sebagai agen antioksidan mampu menghapus radikal bebas, lalu menghalang radikal bebas daripada menyerang reseptor glukokortikoid. Maka, reseptor glukokortikoid dapat berfungsi dengan baik dan mekanisme negatif maklum balas dapat diaktifkan. Seterusnya menyebabkan berlaku perencatan pada penghasilan hormon $\mathrm{CRH}$ dan $\mathrm{ACTH}$, lalu mengurangkan sekresi hormon kortisol dalam keadaan stres.

Situasi stres juga turut menyumbang kepada penghasilan katekolamin seperti norepinefrin di dalam sistem saraf simpatetik untuk meningkatkan tahap kebangkitan dan kesedaran seseorang. Peningkatan norepinefrin di dalam kumpulan tikus stres tanpa rawatan berbanding kumpulan tikus normal. Peningkatan norepinefrin ketika stres juga turut ditunjukkan dalam kajian Nur Azlina et al. (2012). Kumpulan rawatan vitamin E sawit dan tokotrienol pula menunjukkan penurunan aras norepinefrin berbanding kumpulan tikus stres tanpa rawatan. Penggunaan antioksida vitamin E telah membantu dalam pengurangan aras katekolamin.

Radikal bebas yang terhasil ketika stres pada tisu otak akan mengakibatkan peningkatan IL- $1 \beta$. IL- $1 \beta$ terlibat dalam sistem inflamatori, proliferasi sel dan apoptosis. Peningkatan IL-1 $\beta$ akan menyebabkan sistem saraf simpatetik diaktifkan, lalu meningkatkan penghasilan norepinefrin (Pongratz et al. 2014). Mengikut kajian Nur Azlina et al. (2015), tokotrienol dapat menghalang stres oksidatif dengan mengurangkan jumlah IL-1 $\beta$. Hasilnya, aktiviti sistem saraf simpatetik akan berkurangan dan penghasilan norepinefrin juga turut akan berkurang. Vitamin E juga telah dilaporkan mampu mengurangkan stres oksidatif di dalam otak dalam keadaan stres (Sakr et al. 2015; Zaidi \& Banu 2004).

Penghasilan dopamin turut meningkat ketika stres (Gamo et al. 2015). Keputusan kajian ini menunjukkan berlakunya peningkatan dopamin dalam kumpulan tikus stres berbanding kumpulan normal dan pengurangan dopamin dapat ditunjukkan di dalam kedua-dua kumpulan rawatan Vitamin E sawit dan tokotrienol. Selain itu, peningkatan dopamin juga turut menyumbang kepada peningkatan norepinefrin kerana norepinefrin dihasilkan daripada dopamin. Dalam kajian ini turut menunjukkan berlakunya peningkatan aras norepinefrin apabila penghasilan dopamin juga meningkat semasa stres.

Di dalam sistem saraf pusat, katekolamin seperti dopamin, serotonin dan norepinefrin adalah sumber molekul yang penting dalam penghasilan radikal bebas dengan proses penguraian metabolik katekolamin ini dimangkinkan oleh enzim monoamine oksidase (Cohen 1987; Finlay et al. 1995). Proses metabolik dopamin bermula dengan penghasilan 3,4-dihidroksifenilasetik 
asid (DOPAC) melalui aktiviti enzim monoamine oksidase (Cohen \& Spina 1989). Reaksi tindak balas ini akan menyumbang kepada penghasilan radikal bebas hidrogen peroksida $\left(\mathrm{H}_{2} \mathrm{O}_{2}\right)$ (Cohen \& Spina 1989). Hidrogen peroksida seterusnya boleh bertindak balas dengan molekul ion kuprum untuk membentuk radikal bebas paling berbahaya iaitu radikal hidroksil $(\mathrm{OH} \cdot)$ (Cohen \& Spina 1989). Tambahan lagi, katekolamin juga boleh mengalami pengoksidaan-auto untuk menghasilkan radikal superoksida $\left(\mathrm{O}_{2}^{-\cdot}\right)$. Radikal bebas yang terhasil akibat proses metabolisma ini boleh menyebabkan kerosakan pada saraf di tisu otak.

Dengan pemberian antioksida seperti vitamin E sawit dan tokotrienol, aktiviti radikal bebas yang berbahaya ini dapat dihalang. Antioksida seperti vitamin E dapat bertindak balas dengan radikal bebas dan menghalang rantaian peristiwa pembentukan radikal bebas ini daripada berlaku. Kesan aktiviti vitamin E sawit dan tokotrienol dapat mengurangkan kesan buruk katabolisma dopamin yang berlebihan dan kemungkinan mambantu dalam mengawal penghasilan dopamin selain daripada mengurangkan radikal bebas yang terhasil.

Serotonin atau turut dikenali sebagai 'hormon gembira' turut terlibat dalam respons terhadap stres. Aras serotonin dalam kajian ini menurun di dalam kumpulan tikus stres berbanding kumpulan tikus normal. Pemberian rawatan vitamin E sawit dan tokotrienol kepada tikus yang didedahkan kepada stres dapat mengawal penghasilan serotonin sehingga hampir kepada nilai kumpulan normal. Aras serotonin yang rendah telah dikaitan dengan pembentukan depresi pada tikus kajian dan manusia yang telah terdedah kepada stres (Cowen et al. 2008, 2002; Puglisi-Allegra 2015). Ini mungkin diakibatkan oleh peningkatan hormon kortisol yang mengaruh perubahan pada sistem neurotransmiter seperti neurotransmiter serotonin. Kajian Coppen dan Doogan (1988) membuktikan triptofan iaitu prekursor penghasilan serotonin, teralih kepada laluan kinurunin di dalam hati apabila aras kortisol menjadi tinggi. Keadaan ini seterusnya akan menyebabkan kekurangan kebolehdapatan triptofan untuk proses sintesis serotonin di dalam otak (Coopen \& Doogan 1988; Puglisi-Allegra 2015). Laluan kinurinin merupakan satu proses metabolik untuk menghasilkan nikotinamida adenina dinukleotida (NAD+) daripada hasil degradasi asid amino triptofan. Justeru, situasi stres yang menyebabkan penghasilan kortisol yang tinggi telah menyumbang kepada penurunan proses sintesis serotonin di dalam otak.

Vitamin E sawit dan tokotrienol, kedua-duanya merupakan bahan terbitan daripada vitamin $\mathrm{E}$ dan yang membezakannya ialah jumlah komposisi tokoferol dan tokotrienol. Rawatan Vitamin E sawit merupakan campuran tokoferol dan tokotrienol manakala rawatan tokotrienol pula sepenuhnya terdiri daripada tokotrienol. Dalam kajian ini, kedua-dua rawatan Vitamin E sawit dan tokotrienol tidak menunjukkan perbandingan yang signifikan dalam memberikan kesan antioksida kepada aras hormon dan katekolamin.
Menurut Serbinova dan Packer (1994), tokotrienol menunjukkan kadar penumpukan yang lebih perlahan di dalam tisu jantung dan hati berbanding tokoferol. Disebabkan rawatan Vitamin E sawit di dalam kajian ini mempunyai kandungan $30 \%$ tokoferol dan kandungan $70 \%$ tokotrienol, ia membuatkan aktivitinya menjadi lebih kurang sama seperti rawatan $90 \%$ tokotrienol. Komposisi tokoferol di dalam rawatan vitamin E sawit membantu dalam mempercepatkan kadar penumpukannya di dalam tisu tetapi vitamin E sawit masih lagi mempunyai $70 \%$ tokotrienol dan hal ini menyebabkan kadar penumpukan vitamin E sawit tidak menjadi berbeza berbanding $90 \%$ tokotrienol. Kadar penumpukan mampu mempengaruhi kebolehdapatan antioksida vitamin E sawit dan tokotrienol pada tisu otak. Sekiranya kadar penumpukan pada tisu otak tinggi, maka kesan aktiviti antioksida juga akan menjadi tinggi berbanding kadar penumpukan yang rendah. Walau bagaimanapun, kedua-dua vitamin E sawit dan tokotrienol menunjukkan aktiviti antioksida yang serupa dan mampu menghapus radikal bebas.

\section{KESIMPULAN}

Pendedahan kepada stres imbobilisasi rendaman air dapat mengaruh respon stres kepada tikus. Ini dibuktikan dengan peningkatan hormon $\mathrm{CRH}, \mathrm{ACTH}$, norepinefrin dan dopamin di dalam otak tikus. Pemberian suplementasi vitamin E sawit dan tokotrienol kepada tikus adalah efektif dalam menurunkan kepekatan $\mathrm{CRH}, \mathrm{ACTH}$, norepinefrin dan dopamin. Manakala, kepekatan serotonin dapat dikawal sehingga hampir kepada aras normal. Tiada perbezaan kesan suplementasi vitamin E sawit dan tokotrienol apabila dibandingkan, malah kesannya hampir sama dalam mempengaruhi aras $\mathrm{CRH}$, ACTH, norepinefrin, dopamin dan serotonin. Keputusan kajian ini mencadangkan bahawa suplementasi vitamin E sawit dan tocotrienol mampu mengurangkan respon stres yang boleh membawa kemudaratan pada badan.

\section{PENGHARGAAN}

Penyelidikan ini telah dibiayai oleh geran penyelidikan Universiti Kebangsaan Malaysia UKM-067-DLP-2011. Ucapan penghargaan juga kepada ExcelVite Sdn Bhd yang membekalkan tokotrienol dan vitamin E sawit yang digunakan dalam penyelidikan ini.

\section{RUJUKAN}

Aggarwal, B.B., Sundarm, C., Prasad, S. \& Kannapan, R. 2010. Tocotrienols, the vitamin $\mathrm{E}$ of the 21st century: Its potential against cancer and other chronic diseases. Biochemical Pharmacology 80(11): 1613-1631.

American Psychological Association. 2017. Stresses in America. New York: American Psycological Asociation.

Bardhan, J., Chakraborty, R. \& Raychaudburi, U. 2011. The 21 st century form of vitamin E-Tocotrienol. Current Pharmaceutical Design 17(21): 2196-2205. 
Budin, S.B.,Taib,I.S., Jayusman, P.A.,Chiang,H.H., Ramalingam, A., Ghazali, A.R. \& Mohamed, J. 2014. Ameliorative effect of palm oil tocotrienol rich fraction on brain oxidative stress in fenitrothion-administered rats. Sains Malaysiana 43(7): 1031-1036.

Cohen, G. 1987. Monoamine oxidase, hydeogen peroxide and Parkinson's disease. Advances in Neurology 45: 119-125.

Cohen, G. \& Spina, M.B. 1989. Deprenyl suppresses the oxidant stress associated with increased dopamine turnover. Annals of Neurology 26: 689-690.

Coppen, A. \& Doogan, D. 1998. Serotonin and its place in the pathogenesis of depression. Journal of Clinical Psychiatry 21(2): 89-97.

Cowen, P.J. 2002. Cortisol, serotonin and depression: all stressed out? The British Journal of Psychiatry 180(2): 99-100.

Cowen, P.J. 2008. Serotonin and depression: Pathophysiology mechanism or marketing myth? Trends in Pharmacological Sciences 29(9): 433-436.

Finlay, J., Zigmoid, M. \& Abercrombie, E. 1995. Increased dopamine and norepinephrine realease in medial prefrontal cortex induced by acute and chronic stress: Effect of diazepam. Neuroscience 64(3): 619-628.

Gamo, N.J., Lur, G., Higley, M.J., Wang, M., Paspalas, C.D., Vijayraghavan, S., Yang, Y., Ramos, B.P., Peng, K., Kata, A., Boven, L., Lin, F., Roman, L., Lee, D. \& Arnsten, A.F.T. 2015. Stress impairs prefrontal cortical function via $\mathrm{D}_{1}$ Dopamin receptor interactions with hyperpolarization activated cyclic neucleotide-gates channels. Biological Psychiatry 78(12): 860-870.

Halliwell, B. 1996. Antioxidants in human health and disease. Annual Review of Nutrition 16: 33-50.

Halliwell, B. 2006. Reactive species and antioxidants: Redox biology is a fundamental theme of aerobic life. Plant Physiology 141(2): 312-322.

Hood, R.L. 1995. Tocotrienol and cholesterol metabolism. In Nutrition, Lipids, Health and Disease. Champaign, Illinois: AOCS Press. pp. 96-103.

Hsu, D.T., Lombrao, K.A., Bakshi, V.P., Balachandram, J.S., Roseboom, P.H. \& Kalin, N.H. 2001. Acute stress-induced increases in thalamic CRH mRNA are blocked by repeated stress exposure. Brain Research 915(1): 18-24.

Ibrahim, A.A.I., Kamisah, Y., Nafeeza, M.I. \& Nur Azlina, M.F. 2012. The effects of palm vitamin E on stress hormone levels and gastric lesions in stress induced rats. Archive of Medical Science 8(1): 22-29.

Lundberg, U. 2002. Psychophysiology of work: Stress, gender, endocrine response and work related upper extremity disorders. American Journal of Industrial Medicine 41(5): 383-392.

Mahar, I., Bambico, F.R., Mechawar, N. \& Nobrega, N. 2014. Stress, serotonin and hippocampal neurogenesis in relation to depression and antidepressant effects. Neuroscience \& Biobehavioral Reviews 38: 173-192.

Marinelli, M. \& Piazza, P.V. 2002. Interaction between glucocorticoid hormones, stress and stress hormones on human cognition: Implications for the field of brain and cognition. Brain and Cognition 65(3): 209-237.

Nur Azlina, M.F., Kamisah, Y., Chua, K.H., Ibrahim, I.A.A. \& Qodriyah, H.M.S. 2015. Preventive effects of tocotrienol on stress-induced gastric mucosal lesions and its relation to oxidative and inflammatory biomarkers. PloS One 10(10): e0139348
Nur Azlina, M.F. \& Nafeeza, M.I. 2008. Tocotrienol and a-tocopherol reduces corticosterone and noradrenalin levels in rats exposed to restraint stress. Pharmazie 63: 890-892.

Nur Azlina, M.F., Ibrahim, A.I., Kamisah, Y. \& Nafeeza, M.I. 2012. Palm vitamin E reduces catecholamines, xanthine oxidase activity and gastric lesions in rats exposed to waterimmersion restraint stress. BMC Gastroenterology 12: 54.

Penyedia pekerjaan global, Petunjuk ekonomi Global Regus. 2013.

Pongratz, G. \& Straub, R.H. 2014. The sympathetic nervous response in inflammation. Arthritis Research \& Therapy 16: 504.

Puglisi-Allegra, S. \& Andolina, D. 2015. Serotonin and stress coping. Behavioural Brain Research 277: 58-67.

Romero, M.L. \& Butler, L.K. 2007. Endocrinilogy of stress. International Journal of Comparative Psychology 20(2): 89-95.

Sakr, H.F., Abbas, A.M. \& El Samanoudy, A.Z. 2015. Effect of vitamin $\mathrm{E}$ on cerebral cortical oxidative stress and brainderived neurotrophic factor gene expression induced by hypoxia and exercise in rats. Journal of Physiology and Pharmacology 66(2): 191-202.

Schiavone, S., Jaquet, V., Trabace, L. \& Krause, K.H. 2013. Severe life stress and oxidative stres in the brain: From animal models to human pathology. Antioxidants \& Redox Signaling 18(12): 1475-1490.

Serbinova, E.A. \& Packer, L. 1994. Antioxidant and biological activities of palm-oil vitamin E. Food and Nutrition BulletinUnited Nations University 15: 138-138.

Taridi, N.M., Abd Rani, N., Abd Latiff, A., Wan Ngah, W.Z. \& Mazlan, M. 2014. Tocotrienol rich fraction reverses agerelated deficits in spatial learning and memory in aged rats. Lipids 49: 855

Tort, L. \& Teles, M. 2011. The endocrine resposes to stress: A coparative view. Dlm. Basic and Clinical Endocrinology Up-to Date, disunting oleh Akin, F. Croatia: Intech Europe. pp. 265-286.

Tsigos, C., Kyrou, I. \& Kassi, E. 2000. Stress, endocrine physiology and pathophysiology. Dlm. Title of Book, disunting oleh De Groot, L.J., Chrousos, G., Dungan, K., Feingold, K.R., Grossman, A., Hershman, J.M., Koch, C., Korbonits, M., McLachlan, R., New, M., Purnell, J., Rebar, R., Singer, F. \& Vinik, A. South Dartmouth (MA): MDText. com, Inc.https://www.ncbi.nlm.nih.gov/books/NBK278995/. Updated 2016, Mar 10.

Zaidi, S.M. \& Banu, N. 2004. Antioxidant potential of vitamins $\mathrm{A}, \mathrm{E}$ and $\mathrm{C}$ in modulating oxidative stres in rat brain. Clinica Chimica Acta 340(1-2): 229-233.

Nur Azlina Mohd Fahami Mail*

Jabatan Farmakologi, Fakulti Perubatan

Universiti Kebangsaan Malaysia

Jalan Yaacob Latiff, Bandar Tun Razak

56000 Cheras, Kuala Lumpur, Wilayah Persekutuan Malaysia

Naddiah Syafiqah Ramli Mail \& Elda Surhaida Latif Mail

Program Bioperubatan, Fakulti Sains Bersekutu

Universiti Kebangsaan Malaysia

Jalan Raja Muda Abdul Aziz

50300 Kuala Lumpur,Wilayah Persekutuan

Malaysia 
*Pengarang untuk surat-menyurat; email: nurazlinamf@ukm.

edu.my

Diserahkan: 30 Mac 2018

Diterima: 5 Jun 2018 